\title{
Design and Development of the Public Service Information: A Case Study of Villages in District East Tombariri, Minahasa-Indonesia
}

\author{
Harson Kapoh, \\ Fanny Doringin \\ Dept. of Informatic Engineering \\ Manado State Polytechnic \\ Manado 95252, North Sulawesi \\ Indonesia
}

\author{
Meiny M. Taju \\ Departement of Electrical Engginering \\ University of Indonesia Development \\ Manado Indonesia
}

\begin{abstract}
Data from the Central Bureau of Statistics the population of Indonesia in 2010 was as much as 237641326 inhabitants. Number of people a lot of this must have an impact on service to the community. According to Law No.25 of 2009 standard of service can help with public service information system or information system and presented manually or electronically. We have also performed a literature review and found that the information in Minahasa, public services are still not optimal because there are some obstacles such as concepts of village administration that have not been implemented properly by the village government. For that reason, we also have to develop information systems for local public services Minahasa namely the villages in the district Tombariri East as a case study. The purpose of this study was to produce a concept of information system implemented in an application to help public service based multi-user in the villages in the district of Minahasa. This system has been designed to be used to service the needs of off line and on-line. This public information service system main function is to assist employees in the village to serve the manufacturing speed up the letters became public needs directly from the lowermost levels of government and is integrated with the village office. Also this system there is a facility storing data on population and letter formats required.
\end{abstract}

\section{Keywords}

Usecase Diagram, Entity Relationship Diagram, Data Flow Diagram

\section{INTRODUCTION}

Indonesia is a country with a population of approximately 237 641326 , the data center statistics 2010. This amount makes Indonesia the country with the largest population 4th in the World. The population that many of these have an impact on public services, had to be considered by the central government to the local government in the village and the village.

Since the Indonesian government imposed regulations regional autonomy with the law of local government, namely Law No. 2 of 1999, which was then in the subsequent development is replaced by Act No. 32 of 2004 as last amended by Law No. 12 Year 2008 on the Second Amendment Law Number 32 Year 2004 on Regional Government.

If we look closely, basically the mission and objectives of decentralization policy as mandated in the legislation one of which is to improve the quality and quantity of public services and the welfare of society [7].
The quality of public services in Indonesia is still far from a state of effectiveness and efficiency expected by all parties. Many arguments put forward in response to questions about the cause of a ineffectiveness and inefficiency in the public service, among others, moral and mental apparatus is low, low managerial competence, kentalnya interests of certain political groups, low public participation [7].

Act No. 25 of 2009 on Public Service also stated that today's public service is still faced with conditions that do not correspond to the needs and changes in various areas of society, nation and state (Act No.25 of 2009). This is also evidenced by research by Lydia Natalia Seysi Dayoh in Minahasa district, precisely in the village Tompaso II in which the function of public services and administrative services to the community such as in regard to obtaining a certificate of maintenance of the e-ID card, family card, and so forth, in the village Tompaso II districts Tompaso west district minahasa still hampered because it is still done manually [5] and is supported by research by Adelfia Crestofiane Mangimpis in the villages of districts Amurang East South Minahasa regency that the implementation of the policy of village administration in the public service have the constraints affecting the implementation of the policy namely the lack of facilities and infrastructure such as computers, print, desks, chairs, file cabinets, thereby reducing the performance of the public service [6].

Science in the field of information technology, especially for electronic data processing is growing. According Jogiyanto, information systems development methodology has been very good since the beginning of 1970 so as to develop a model of information becomes more easily [4]. Many organizations today started and is already applying information technology due to the fact of information technology can help in the decision making, planning and transactions quickly, accurately and relevant [8]

As in Law Public services in 2009 in maklumatkan public service is a written statement that contains the entire details of the obligations and the promise contained in service standards, service standards can help with information systems of public service or system information includes the storage and management of information and mechanisms for the delivery of information from the Operator to the community and vice versa in the form of oral, written Latin, written in braille letters, language picture, and / or the local language, and presented in a manual or electronic [13]. So a team of researchers think it helps a computer-based information system technology is generated that can be used a lot of people, generated to assist in the public service to be 
used in government in villages, especially in the district of East Tombariri Minahasa regency.

For that reason, the research team will conduct research in the field of information technology for the implementation of the concept of information systems in an application to help the productivity of public services-based Multi-User in the villages of the District Tombariri East in Minahasa that can be used to assist in the process of service and public administration.

The purpose of this study is the resultant of information technology in the form of application programs that can later be used by the villages, especially employees and communities in Minahasa District of paperwork that can help in improving the productivity of public services to the public for data processing be faster.

\subsection{Related Research}

Lydia Natalia Seysi Dayoh on the study, the researchers describe the concepts of the role of village government in improving the capability and performance in serving the communities where it is one of the important things regarding the function of government. That function is administrative services to the community. as in the management of e-ID card, family card, and so forth, in the village Tompaso II subdistrict west district minahasa Tompaso still hampered [5].

Adelfia According to research done by taking the data which the random sample method (random sampling). Therefore, from 8 (eight) villages in the district of South Minahasa Regency East Amurang authors take three (3) villages of Lopana, Pinaling village and the village of Tower City as a sample. Because of these three villages have already run the administration of the village well and there is not yet fully run the administrative villages and also be seen from a distance or location in the district office [6].

The village administration policy implementation in the public service have the constraints affecting the implementation of these policies is the lack of facilities and infrastructure such as computers, print, desks, chairs, file cabinets and does not function properly the existing village office. Thus it can be concluded that the implementation of the policy of village administration in the public service in three villages in the districts Amurang East where the implementation of administrative villages have not been fully implemented since due to the lack of existing resources and infrastructure that support the administration in service to the community [6].

The findings of the study at the village office Kebonsari then been one of the problems related to Information Technology. The problem is demographic data processing using a conventional still use the book notes that data collection is still frequently encountered errors. The solution to overcome this problem is to use demographic data processing information system based on computer. The advantages using this system which will facilitate Kebonsari village officer in carrying out duties population census. This information system will reduce errors that occur in the management of data processing such as data villagers Kebonsari double population [3]. Design of Information Systems Data
Processing Kebonsari Population in the village can be developed into the process of implementation and application programming desktop.

The results of this study indicate before adoption of the SID in the Village Eggplant public service is not prime. After the implementation of SID in 2009 until early 2012, the public service has increased. It can be concluded that the application of information systems in villages can significantly increase the effective public services in the form of speed, accuracy and straightforward in providing the service [1]. But there are factors precision and style of service delivery will also affect the public service kefektivitasan village. Factors austerity, in the form of thoroughness in providing services to the public. Factors style of service delivery, ie politeness, polite, and friendly village in providing services to the community [1].

Research Team will use as the basis of the above results in the development of the concept of information systems for public service productivity-based multi-user that can be used on-line.

One of the functions of the village administration is administrative services to the community. as in the management of e-ID card, family card, and so forth, in the village Tompaso II sub-district west district minahasa Tompaso still hampered [5]. This could be an indication that not only Tompaso Village II that have the same problem in Minahasa district. In the study conducted Adelfia research conducted in the District of South Minahasa Regency East Amurang Adelfia take three (3) villages of Lopana, Pinaling village and the village of Tower City as a sample [6]. Because of these three villages have already run the administration of the village well and there is not yet fully run the administration of the existing village.

The village administration policy implementation in the public service have the constraints affecting the implementation of these policies is the lack of facilities and infrastructure such as computers, print, desks, chairs, file cabinets and does not function properly the existing village office. Thus it can be concluded that the implementation of the village administration policies were not fully completed because due to the lack of existing resources and infrastructure that support the administration in the public service.

\section{RESEARCH METHODOLOGY}

The research methodology used comprises several research methods that will be used to solve or answer problems that have been pointed out previously. The research method as follows,

\subsection{Research flow Diagram}

This research uses a flowchart is used to help solve the problem of the study by producing models that can make the performance of the public service to become productive.

Stages of research based on the planned diagram is as shown in Figure 1. This research began with surveys, perform system analysis based on the survey data are taken as needed to be used for system design and applied on the computer. 


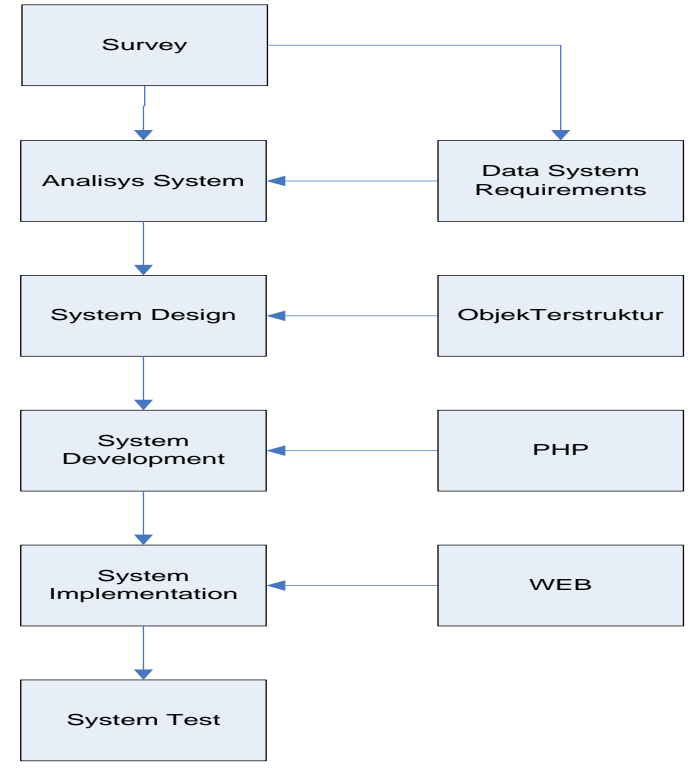

Fig 1: Flow Diagram

\subsection{Research Methode}

The methods used for this research is a survey

- Method using the linkert scale for assessment.

- $\quad$ Field study methods (observation study) and the study of literature (library study). This method is used to identify the problem based on the data found.

- Interview methods, used to get the data to identify systems that are running and that will be developed.

- Questionnaire method, used to find out the level of employee participation in providing information.

- Method of architecture namely methods later used to describe the system based on the results of the analysis.

- Functional testing method using blackbox to see results when this system is executed whether or not error system by performing a test data, test the server response and displays the appropriate information.

- Evaluation of interface using the respondent's questionnaire method to test the performance of the user according to whether the system is easy to use or not.

\subsection{Analisys and Design of System}

This study uses several kinds of analytical tools to describe the logic of the system. Analysis tools that are used to help the development of applications in order to implement the concept of a public service productivity. Some of the analytical tools needed to assist in the analysis of this research are as follows [9]:

- Flow chart is a diagram that is used to analyze the system and program

- Data Flow diagram is a diagram that is used to analyze the data flow that occurs in the system that will be in the wake of the

- Entity Relationship Diagram is a diagram that is used to analyze the relationships between the entities in the system to be built

- Use case diagram is a diagram that is used to analyze anyone associated applications and use the functions of the system.

\subsection{Model Design}

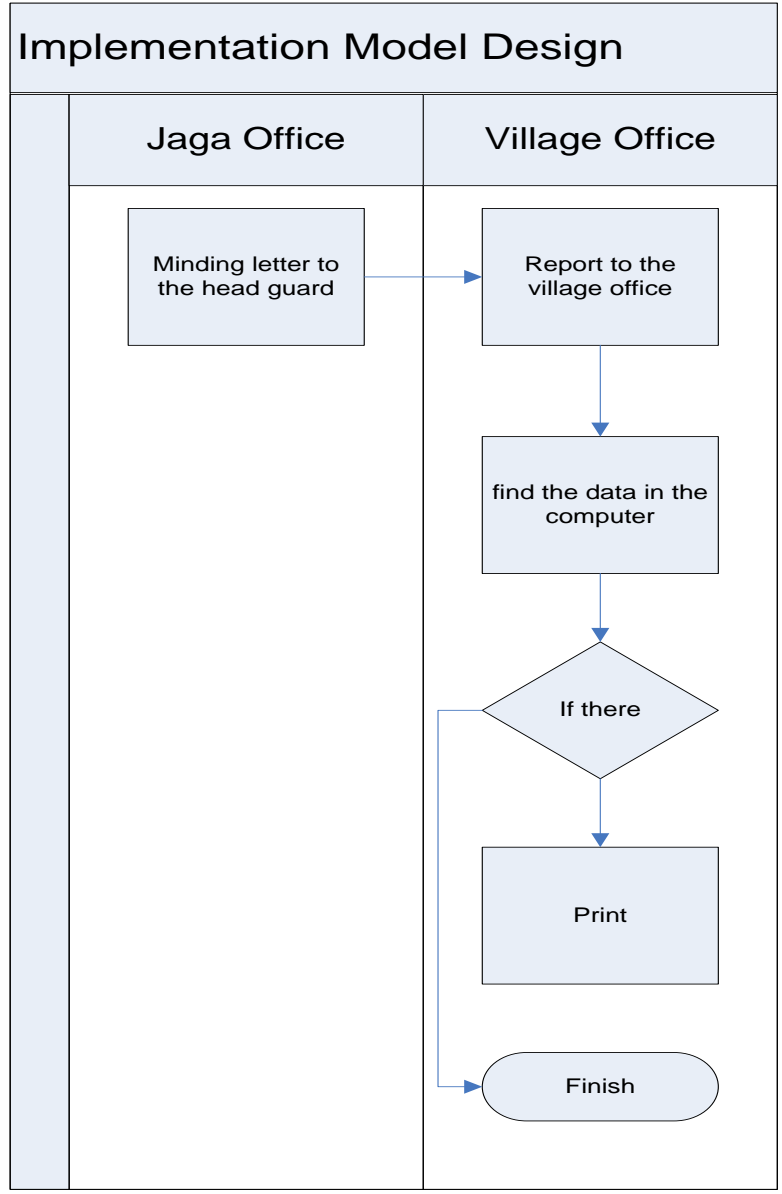

Fig 2: Model Design

\section{RESULT AND TEST}

Based on the data collected to be used to make a system or application that can help improve the productivity of public services in the villages of East tombariri sub Regency of Minahasa in North Sulawesi, then using the methodology suggested above results in the following can exist

\subsection{Result}

Results from data capture through observation, study of literature as well as interviews already done to be used to analyze, design, develop and implement the system can be seen as follows:

\subsubsection{Studi Literature}

The results of the study of literature found several factors that affect productivity in the public service in particular the Ministry of dipedesaan in Indonesia more specifically in the Regency of Minahasa in making service becomes the maximum. Those factors are the intricate factors, such as accuracy in providing service to the community. Factors, namely the granting of service style attitude of courteous, polite, and friendly village in the devices providing service to the community. Resource factors, namely the lack of resources available and also the completeness of facilities and infrastructure that support the Administration in service to the community. 


\subsubsection{Survey}

Based on factor-factor found in the study of literature then to prove further that the factors found in the study of literature there is also in villages in the subdistrict Tombariri East then conducted the survey by selecting random 30 respondents with the same characteristics i.e. residents with proof of ID, ever dealt with public service in the village of each such certificate etc. A survey conducted in 9 villages that existed in the villages in the subdistrict Tombariri East. Based on the study of the study of literature that was with factors already set forth above to see whether those factors also affect service to the community in the villages located in the subdistrict of East Tombariri. After the survey results obtained as follows

Table 1. Factors affecting service

\begin{tabular}{|l|l|l|l|l|l|l|}
\hline \multirow{2}{*}{ No } & \multirow{2}{*}{ Factor-factor } & \multicolumn{5}{|c|}{ Scores answers } \\
\cline { 3 - 7 } & & $\mathbf{5}$ & $\mathbf{4}$ & $\mathbf{3}$ & $\mathbf{2}$ & $\mathbf{1}$ \\
\hline 1 & $\begin{array}{l}\text { factor } \\
\text { austerity }\end{array}$ & & 5 & 14 & 8 & 3 \\
\hline 2 & factor style & 3 & 11 & 6 & 7 & 3 \\
\hline 3 & $\begin{array}{l}\text { Resource } \\
\text { factors }\end{array}$ & & 10 & & 10 & 10 \\
\hline
\end{tabular}

Likert Scale used for scoring, with each answer given a score of 1-5 with the following explanation:

Resource factors:

1. Very Incomplete $(\mathrm{STL})=1$

2. Incomplete $(\mathrm{TL})=2$

3. Simply Complete $(\mathrm{CL})=3$

4. Complete $(\mathrm{L})=45$. Sangat Lengkap $(\mathrm{SL})=5$

Austerity factors:

1. Strongly Meticulously $($ STC $)=1$

2. Carefully $(\mathrm{TS})=2$

3. Self Quiz $(\mathrm{CC})=3$

4. Carefully $(\mathrm{C})=4$

5. Very Carefully $(\mathrm{SC})=5$

Factors style of service:

1. It's Not Good (STB) $=1$

2. No Good $(\mathrm{TB})=2$

3. Good Enough $(\mathrm{CB})=3$

4. Good $(B)=4$

5. Very Good $(\mathrm{SB})=5$

The results of the survey showed that the three factors above are factors rigor, style and everything turned out resources also occurred in villages in the district of East Tombariri Minahasa regency.

This study will be followed by an analysis of system requirements, design and application development on the basis that the resources in the villages in the district of East Tombariri existence is not up to the time of public service are not yet using information technology.

\subsubsection{Arsitecture system}

The design architecture of the proposed system is a system of public services productivity information based multi-user in the villages as shown below.

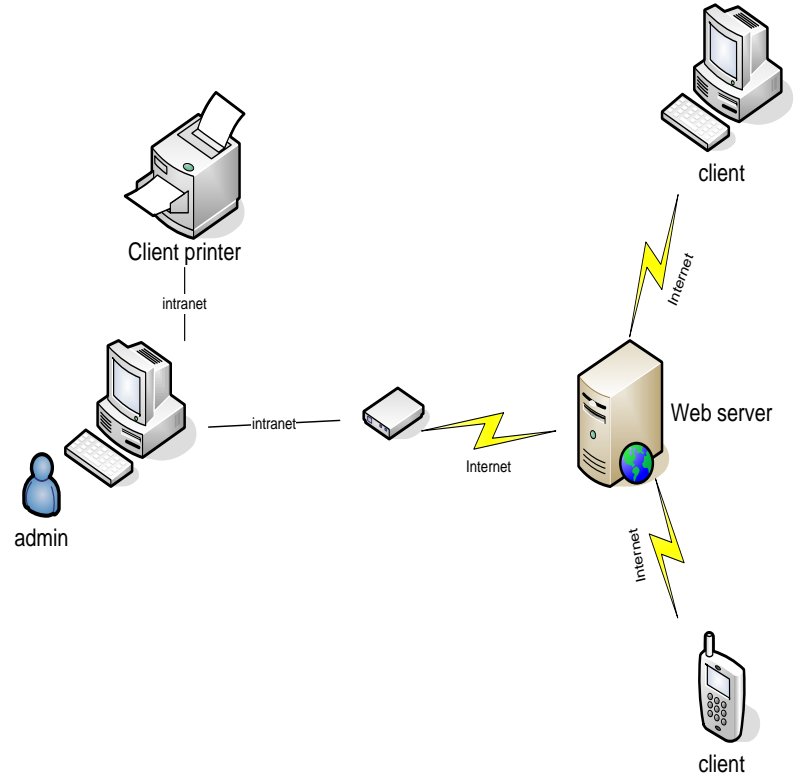

Fig 2: Arsitecture system

Fig. 2 is a picture that describes the design of the concept of information systems to aid the productivity of public services based multi-user villages in the Eastern districts Tombariri Minahasa regency. Fig. 2 seen that this scheme involves a server as a data center, clients as users of the system ie village or district employee who called the village. This design allows the client will use the system for the maintenance of public certificate with a computer, laptop or smartphone. This hardware is connected to one another through the Internet starting from the bottom level of village government called Jaga.

\subsubsection{Disain Sistem}

Based on the analysis of the importance of the system of computer-based system design services using such data flow diagram in fig. 3 .

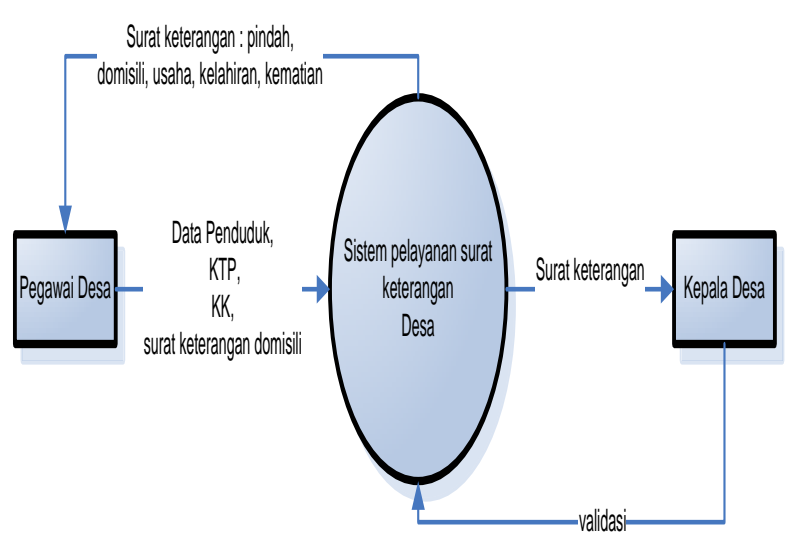

Fig 3: Conteks diagram

\subsubsection{Data flow diagram}

The results of the decomposition diagram shows the context in Fig. 3 is logical 3 processes in the service system certificate ie login village, residents and letters. 


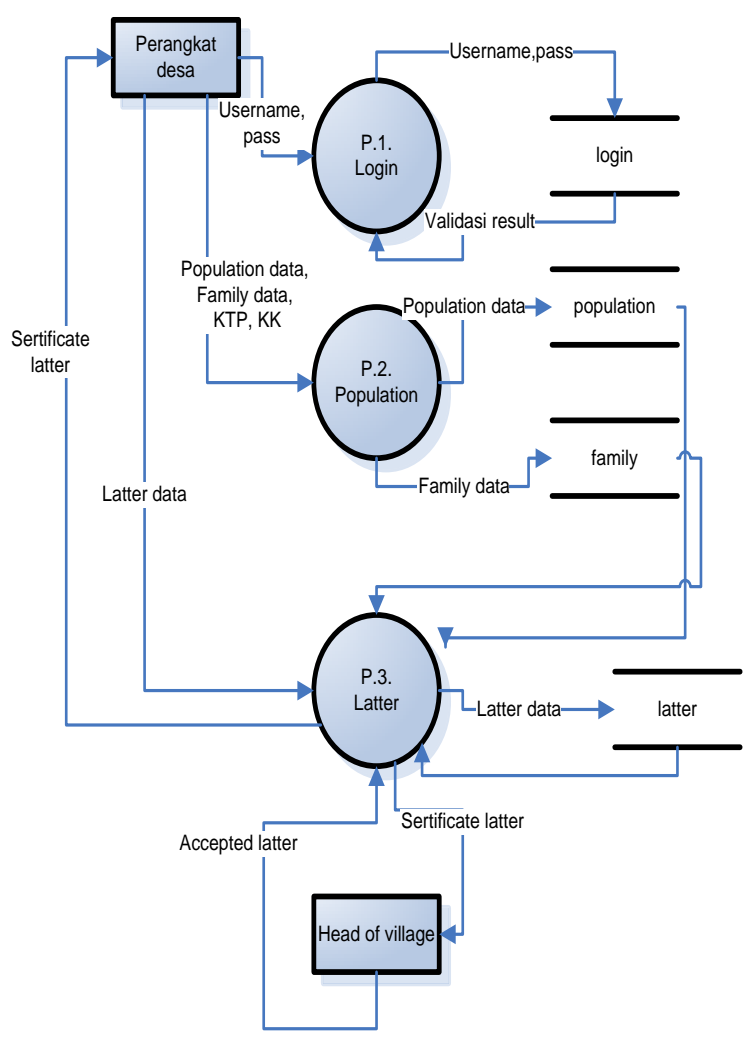

Fig 4: Data Flow Diagram

\subsubsection{Use Case}

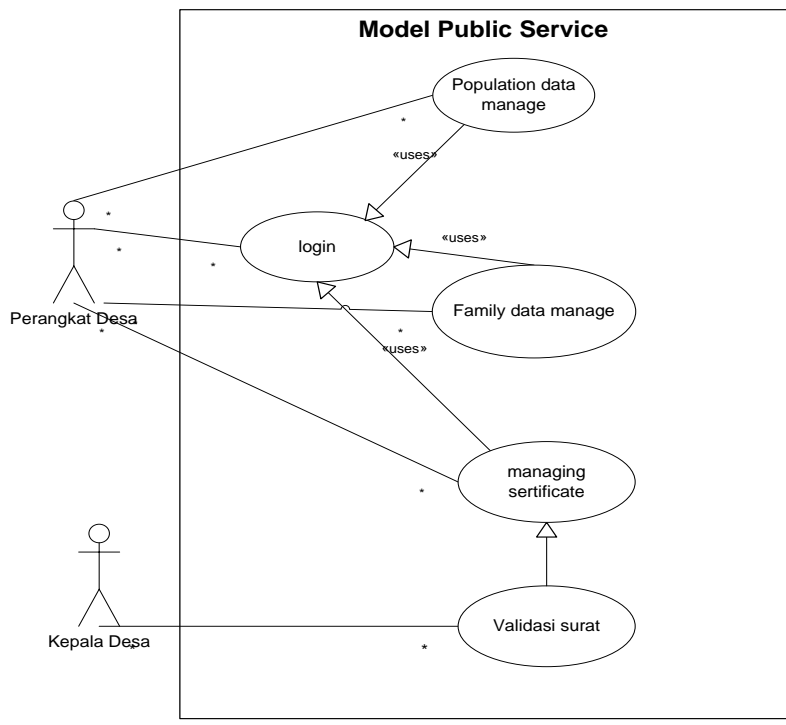

Fig 5: Use case diagram

\subsubsection{Applications}

The interface of the program or applications can be based on analysis and system design. Fig. 7 is the implementation of interface design application systems.

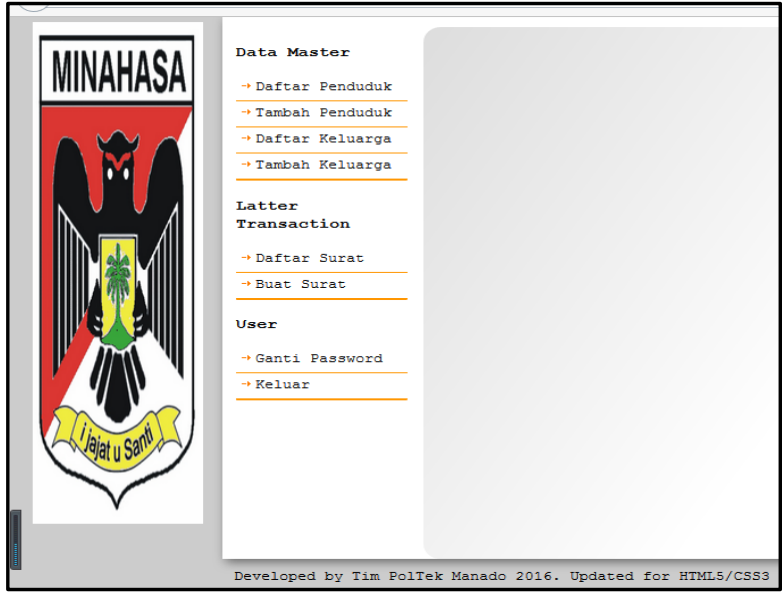

Fig 6: Initial of interface

The interface of the application consists of a list of existing residents, resident added, listing the family, plus family, create a certificate.

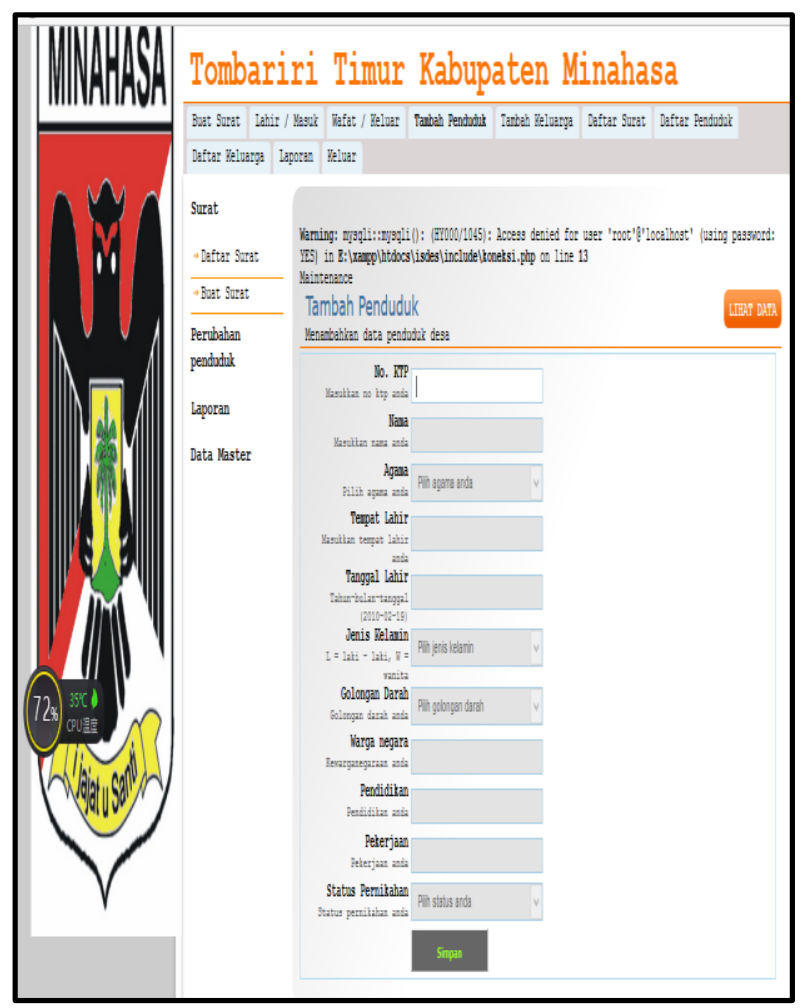

Fig 7: Input data population

Users can fill in population data as master data on the population register menu by clicking the add population as in fig 7. 


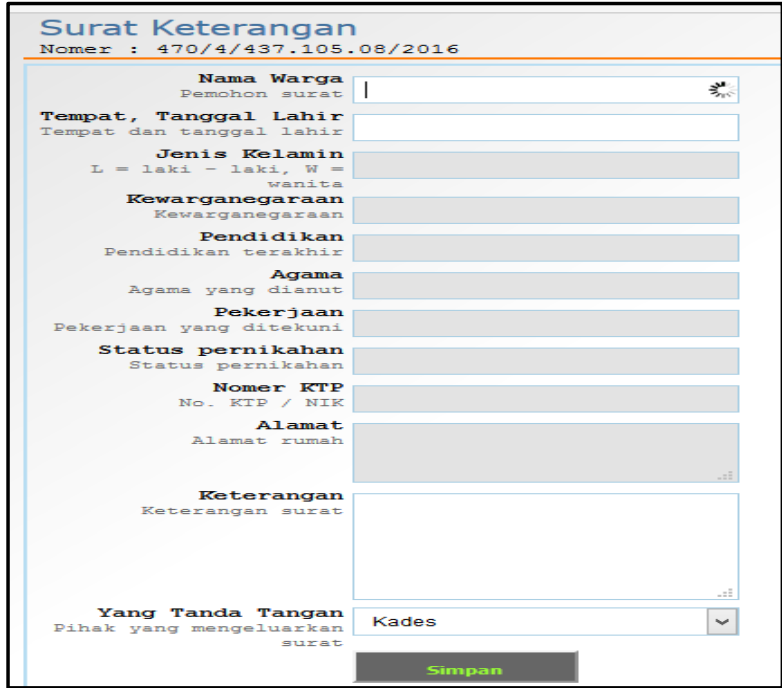

Fig 8: Display certificate process

Views on fig. 8 is the form that is used to populate the data for such as obtaining a certificate, birth, kemaitian, domicile and business. Initial studies conducted at the time showed that the maintenance of a letter by the people in the village office take a long time because people had to do from the bottom level of government that case. While in the case of government, the community will take care of a cover letter below to the level of village government. In the village administration society will show a letter of introduction from the government in case in which community members were registered. It will take a long time. For that reason, in kembangkaan system to speed up the process to obtain the architecture in Fig. 2.

Table.2 Time difference information service

\begin{tabular}{|l|l|l|}
\hline Function & $\begin{array}{l}\text { System without } \\
\text { using app }\end{array}$ & System using app \\
\hline $\begin{array}{l}\text { Time to take care } \\
\text { of a letter of } \\
\text { introduction from } \\
\text { the lower levels of } \\
\text { government (in } \\
\text { jaga) }\end{array}$ & $\begin{array}{l}\text { Time is needed is } \\
10-16 \text { minutes }\end{array}$ & $\begin{array}{l}\text { Time is needed is } \\
3-5 \text { minutes }\end{array}$ \\
\hline $\begin{array}{l}\text { Time searching } \\
\text { for files in the } \\
\text { village office }\end{array}$ & $\begin{array}{l}\text { Time is needed is } \\
3-7 \text { minutes }\end{array}$ & $\begin{array}{l}\text { Time is needed is } \\
1-2 \text { minutes }\end{array}$ \\
\hline $\begin{array}{l}\text { Time to make a } \\
\text { letter }\end{array}$ & $\begin{array}{l}\text { Time is needed is } \\
8--16 \text { minutes }\end{array}$ & $\begin{array}{l}\text { Time is needed is } \\
2-5 \text { minutes }\end{array}$ \\
\hline
\end{tabular}

Table 2 describes the experiments conducted on the application system to see the difference in results when using applications and systems that do not use the system. These trials have been conducted using the 10 respondents who have the same qualifications that have their own laptop or pc, master the Windows operating system, work with a computer at least 5 years. The workings of this system is that can be directly used by the village government under which maintained using the password directly into the system to take care of certain letters and stored in a centralized server so that the letter will be printed in the village and signed by the leader of the village.

\section{CONCLUSION}

The study found that in the villages of districts Tombariri in public service there are several obstacles to be grouped are three factors, namely austerity, style of service and resources.
For further research we took one of them is the factor of such resources in the documents, in the village do not use computers or information technology as in mandated by law. So we developed an application that helps a community service based information systems that can produce highproductivity services to the public. Applications in the design can be directly used by government officials at the level of the guard and do not need to create a cover letter to the village. In the village office of the letter can be directly printed and signed. All letters are made in the government keep stored on the server. Looking ahead for this study are in the unity of the E-Government so the need to create quality and quantity of services. Village location with far-flung districts especially with the district and the community need to also take care of their problems in the district, but the maintenance should be started from the village then the system must be able to anticipate the wider network that is from the village to the district office. So it is also necessary to create a data base that is more structured, and the development of mobile-based systems.

\section{REFERENCES}

[1] Ariski. S (2014), Effectiveness of Care Through Information Systems Desa (Sid) In the village Eggplant Dlingo District of Bantul, e-jurnal Universitas Negeri Yogjakarta volume feb. no 1

[2] Direktorat penelitian dan pengabdian pada masyarakat, 2013., Panduan pelaksanaan penelitian dan pengabdian pada masyarakat di perguruan tinggi

[3] Didik Setiawan, Yhoni Agus Setya Mahendra (2015), On the Population Information System Design Village Office Kebonsari, IJNS - Indonesian Journal on Networking and Security, ijns.org, ISSN: 2302-5700

[4] Jogiyanto., 2005, Analisis dan Disain Sistem, Penerbit Andi

[5] Dayoh Lydia Natalia Seysi, 2014, "Government Role In Increasing Rural Community Service (Studies in Rural Tompaso II District West Tompaso Minahasa)", ejournal.unsrat, tanggal akses 10 april 2015 pada pukul 22.00

[6] Mangimpis Adelfia Crestofiane, 2014, Village Administrative Policy Implementation in the Public Service in Villages Amurang Eastern District of South Minahasa District, e -jurnal unsrat, tanggal akses 10 april 2015 pada pukul 22.35

[7] Kurniawan, A. 2005, Transformation of the Public Service, PT.Pembaharuan, Yogyakarta.

[8] McLeod Raymond Jr., Scell G d, 2004, Management Information System, Prentice Hall, New Jersey, (terjemahan)

[9] Nurcholis Hanif, 2011, Growth \& Government Activity Village, Jakarta: Erlangga.

[10] Pusat Bahasa, 2008, situs resmi Kamus Besar Bahasa Indonesia,http://badanbahasa.kemdiknas.go.id. Tanggal akses 10 April 2015 pada pukul 21.00.

[11] Rosa., Shalahudin., 2011,Rekayasa Perangkat Lunak, Penerbit Modula, Bandung

[12] Undang-Undang Nomor 32 Tahun 2004 Tentang Pemerintahan Daerah.

[13] Undang-Undang Nomor 25 Tahun 2009 Tentang Pelayanan Publik. 